\title{
ANALISIS SALURAN PEMASARAN KOMODITAS PADI (Studi Kasus di Desa Selasari Kecamatan Parigi Kabupaten Pangandaran)
}

\author{
ADEN BAYU RESPATI ${ }^{*}$, MUHAMAD NURDIN YUSUF ${ }^{1}$, DANI LUKMAN HAKIM ${ }^{1}$ \\ ${ }^{1}$ Fakultas Pertanian Universitas Galuh \\ *Email: adenbayuraspati@gmail.com
}

\begin{abstract}
ABSTRAK
Tujuan dari penelitian ini untuk mengetahui 1) saluran pemasaran padi dari petani sampai ke pengecer di Desa Selasari, 2) besarnya marjin pemasaran pada masing-masing lembaga pemasran pada proses pendistribusian padi sawah di Desa Selasari, 3) besarnya keuntungan pemasaran pada masing-masing lembaga pemasaran pada proses pendistribusian padi di Desa Selasari,4) persentase harga yang diterima petani (farmer's share) dalam pendistribusian padi di Desa Selasari. Jenis penelitian yang digunakan adalah metode studi kasus, dengan mengambil kasus di Desa Selasari Kecamatan Parigi Kabupaten Pangandaran. Teknik penarikan sampel untuk Lembaga Pemasaran menggunakan simple random sampling. Sampel yang diambil sebanyak 25 petani dari jumlah populasi sebanyak 204 orang dengan metode acak sederhana(simple random sampling), 20 petani responden, 1 pedagang pengumpul,1 pedagang besar, dan 3 pedagang pengecer. Sedangkan untuk pedagang perantara pengambilan sampelnya menggunakan snowball sampling. Data yang dikumpulkan dianalisis secara deskriftif Hasil penelitian menunjukkan bahwa : Saluran Pemasaran: Petani produsen - Pedagang pengumpul - Pedagang besar - Pedagang pengecer - konsumen. Biaya pemasaran padi sawah yang dikeluarkan ditingkat pedagang pengumpul Rp 400 per kilogram, pedagang besar Rp 890 per kilogram, dan pedagang pengecer Rp 150 per kilogram, sehingga biaya keseluruhan sebesar Rp 1.440 per kilogram. Sedangkan keuntungan pemasaran padi sawah ditingkat pedagang pengumpul yaitu Rp 600 per kilogram, pedagang besar Rp 2.610 per kilogram, dan di pedagang pengecer Rp 1.350 per kilogram, sehingga keuntungan keseluruhan sebesar Rp 4.650 per kilogram. Marjin pemasaran padi sawah ditingkat pedagang pengumpul sebesar RP 1000 per kilogram, pedagang besar Rp 3.500 per kilogram, dan di pedagang pengecer Rp 1.500 per kilogram, sehingga marjin total sebesar Rp 6.000 per kilogram. Farmer's share atau bagian harga yang diterima petani adalah 40 persen dari harga yang dibayarkan konsumen.
\end{abstract}

Kata Kunci: Farmer's share, komoditas padi, saluran pemasaran

\begin{abstract}
The objectives of this research were to find out 1) marketing channels of rice from farmers to retailers in Selasari Village, 2) marketing margins in each supplier institution in the process of distributing lowland rice in Selasari Village, 3 marketing profits in each institution marketing in the process of distributing rice in Selasari Village, 4) the percentage of prices received by farmers (farmer's share) in the distribution of rice in Selasari Village. This type of research was a case study method, by taking a case in Selasari Village, Parigi District, Pangandaran Regency. The sampling technique for Marketing Institutions uses simple random sampling. Samples were taken as many as 25 farmers from a population of 204 people with a simple random sampling method, 20 respondent farmers, 1 collecting trader, 1 large trader, and 3 retailers. As for the intermediary traders the sample collection uses snowball sampling. The data collected was analyzed descriptively The results of the study showed that: Marketing channels: Farmer producers - Trader collectors - Large traders - Traders retailers consumers. The cost of marketing the paddy rice that was incurred at the level of traders was Rp. 400 per kilogram, wholesalers were Rp. 890 per kilogram, and retailers were Rp. 150 per kilogram, so the total cost was Rp. 1,440 per kilogram. While the marketing profit of lowland rice at the level of collecting traders were $R p 600$ per kilogram, wholesalers $R p$ 2,610 per kilogram, and at retailers $R p$ 1,350 per kilogram, so that the overall profit was Rp 4,650 per kilogram. Paddy marketing margin at the level of collecting traders was Rp. 1000 per kilogram, wholesalers Rp. 3,500 per kilogram, and at
\end{abstract}


retailers $R p$. 1,500 per kilogram, so that the total margin was $R p$. 6,000 per kilogram. Farmer's share or part of the price received by farmers was 40 percent of the price paid by consumers.

Keywords: Farmer's share, marketing channel, paddy commodity

\section{PENDAHULUAN}

Proses pembangunan di Indonesia yang merupakan negara agraris, menjadikan sektor pertanian sangat penting bagi perekonomian nasional dan sebagian besar penduduk Indonesia hidup di perdesaan dengan mata pencaharian sebagai petani. Sektor Pertanian memberikan kontribusi yang cukup besar terhadap perekonomian nasional Indonesia dan sebagian besar ekspor Indonesia berasal dari sektor pertanian, sehingga sektor pertanian mempunyai peranan penting dalam penyerapan tenaga kerja serta penyediaan kebutuhan pangan dan sandang bagi penduduk (Yurianto, 2008).

Salah satu komoditas pertanian yang memberikan kontribusi yang cukup besar terhadap perekonomian nasional yaitu tanaman komoditas padi. Tanaman padi adalah salah satu jenis tanaman yang banyak ditanam oleh masyarakat perdesaan, mengingat tanaman padi memiliki peranan yang sangat besar bagi kehidupan masyarakat terutama sebagai sumber mata pencaharianMenurut Makarawung, dkk (2017).

Produksi yang banyak harus ditunjang oleh pemasaran yang baik supaya petani memperoleh hasil yang optimal. Peningkatan hasil produksi akan erat kaitannya dengan pemasaran, meningkatnya produksi harus dapat meningkatkan tingkat pendapatan petani. Untuk mencapai sasaran tersebut, kenaikan produksi yang bersaing dengan produk lain tanpa diimbangi dengan sistem baru pemasaran yang baik justru dapat berakibat menurunnya pendapatan karena jatuhnya harga (Arief, 2005).

Pemasaran merupakan aktifitas yang sangat penting bagi perusahaan untuk mencapai tujuannya. Menurut Kotler dan Keller (2011) pemasaran adalah mengidentifikasi dan memenuhi kebutuhan manusia dan sosial. Sedangkan saluran pemasaran menurut Kotler dan Amstrong (2005) terdiri dari serangkaian lembaga perantara yang akan memperlancar kegiatan pemasaran dari tingkat produsen sampai ke tingkat konsumen.

Pedagang perantara biasanya mengeluarkan biaya dan mendapatkan keuntungan dari proses pendistribusian barang tersebut dan penjumlahan dari kedua komponen tersebut dikenal dengan istilah marjin pemasaran. Besarnya marjin pemasaran selain ditentukan oleh kedua 
komponen tersebut juga ditentukan oleh ukuran teknis panjang pendeknya saluran pemasaran, oleh karena itu semakin panjang saluran pemasaran akan semakin besar pula marjin pemasarannya. Panjang pendeknya saluran pemasaran juga akan mempengaruhi bagian harga yang diterima petani, semakin pendek saluran pemasaran maka bagian harga yang diterima petani (farmer's share) akan semakin tinggi. Berdasarkan latar belakang diatas maka dapat diidentifikasikan masalah-masalah penelitian sebagai berikut : (1) Bagaimana saluran pemasaran padi dari petani sampai ke pengecer di Desa Selasari ? (2) Berapa besarnya marjin pemasaran pada masingmasing lembaga pemasaran pada proses pendistribusian padi di Desa Selasari ? (3) Berapa keuntungan pemasaran dari masing-masing lembaga pemasaran pada proses pendistribusian padi di Desa Selasari ? (4) Berapa persentase harga yang diterima petani (farmer's share) dalam proses pendistribusian padi di Desa Selasari ?. Penelitian ini bertujuan sebagai berikut : (1) Mengetahui saluran pemasaran padi dari petani sampai ke pengecer di Desa Selasari. (2) Mengetahui besarnya marjin pemasaran pada masingmasing lembaga pemasaran pada proses pendistribusian padi di Desa Selasari. (3) Mengetahui besarnya keuntungan pemasaran pada masing-masing lembaga pemasaran pada proses pendistribusian padi di Desa Selasari. (4) Mengetahui persentase harga yang diterima petani (farmer's share) dalam pendistribusian padi di Desa Selasari.

\section{METODE PENELITIAN}

\section{Jenis Penelitian}

Metode penelitian yang digunakan dalam penelitian ini adalah studi kasus, dengan mengambil kasus di Desa Selasari Kecamatan Parigi Kabupaten Pangandaran. Menurut Arikunto (2006), studi kasus adalah suatu penelitian yang dilakukan secara intensif dan terperinci, serta mendalam yang terdapat dalam suatu organisasi, lembaga atau gejala tertentu, baik berupa subyek penelitian secara individu, kelompok, lembaga maupun masyarakat.

\section{Operasionalisasi Variabel}

Untuk lebih memperjelas dan mempermudah penafsiran dalam membahas permasalahan dalam penelitian ini, maka variabel-variabel yang diamati dan berhubungan dengan penelitian ini dioperasionalisasikan sebagai berikut :

1. Saluran Pemasaran Padi dalam penelitian ini adalah seperangkat lembaga yang melaksanakan kegiatan 
(fungsi pemasaran) yang digunakan untuk mengalirkan komoditas Padi dari tangan produsen di Desa Selasari sampai pada pengecer.

2. Biaya pemasaran adalah biaya yang dikeluarkan dalam proses penggerakkan padi dari tangan produsen sampai ke tangan pengecer, biaya pemasaran ini mencakup :

a. Biaya pengangkutan, meliputi biaya bagi kegiatan yang ditujukan untuk menggerakkan barangbarang dari tempat pembelian sampai ke tempat penjualan, dinyatakan dalam satuan $(\mathrm{Rp} / \mathrm{kg})$.

b. Biaya penanggungan resiko yaitu biaya yang dikeluarkan untuk menghindari segala bentuk resiko yang terjadi dan akan terjadi selama pengaliran barang dari produsen ke pengecer, baik karena kerusakan, susut, busuk, kehilangan, turunnya harga dan lain-lain, dinyatakan dalam satuan rupiah per kilogram $(\mathrm{Rp} / \mathrm{kg})$.

c. Biaya retribusi adalah biaya yang dikeluarkan oleh pedagang perantara yang biasanya dikeluarkan secara resmi ( $\mathrm{Rp} / \mathrm{kg})$.

d. Biaya lain-lain meliputi biaya penyimpanan, dan pungutanpungutan penunjang lainnya, dinyatakan dalam satuan rupiah per kilogram $(\mathrm{Rp} / \mathrm{kg})$.

e. Marjin Pemasaran adalah selisih antara harga yang diterima petani produsen dengan harga yang dibayarkan konsumen, dinyatakan dalam satuan rupiah per kilogram $(\mathrm{Rp} / \mathrm{kg})$.

3. Keuntungan lembaga pemasaran merupakan selisih antara marjin pemasaran dengan biaya pemasaran, dinyatakan dalam satuan rupiah per kilogram (Rp/kg).

4. Harga Jual dan harga beli padi merupakan harga rata-rata pada waktu penelitian, dinyatakan dalam satuan rupiah per kilogram $(\mathrm{Rp} / \mathrm{kg})$.

5. Petani padi adalah petani yang membudidayakan padi yang kemudian menjual hasil produksinya.

6. Pedagang pengumpul adalah pedagang yang membeli dan mengumpulkan hasil padi dari petani di tingkat desa, kecamatan yang kemudian menjualnya ke pedagang besar.

7. Pedagang Besar adalah pedagang yang membeli padi dalam jumlah besar dari pedagang pengumpul, kemudian menjualnya ke pedagang pengecer.

8. Pedagang Pengecer adalah lembaga perantara pemasaran yang langsung 
menjual produk-produk yang bersangkutan kepada konsumen akhir.

9. Farmer's Share adalah persentase bagian harga yang diterima petani dari harga yang dibayarkan konsumen, dinyatakan dalam satuan persen $(\%)$.

\section{Teknik Pengumpulan Data}

Data yang dikumpulkan meliputi data primer dan data sekunder.

1. Pengumpulan data primer dilakukan dengan cara wawancara langsung terhadap petani responden dan pedagang perantara dengan menggunakan daftar petanyaan (kuesioner) yang telah disiapkan.

2. Pengumpulan data sekunder dilakukan melalui studi pustaka dan kunjungan ke dinas atau instansi terkait (Dinas Pertanian, BPP, Kantor Desa dan lainlain).

\section{Teknik Penarikan Sampel}

Jumlah petani yang dijadikan responden diambil sebanyak 25 petani, yaitu $10 \%$ dari jumlah populasi 204 orang dengan menggunakan metode acak sederhana (simple random sampling). Menurut Arikunto (2010) simple random sampling adalah teknik penarikan sampel dengan cara meneliti subyek-subyek didalam populasi sehingga semua subyek dianggap sama. Apabila subyek kurang dari seratus lebih baik diambil semua, sehingga penelitiannya merupakan penelitian populasi. Tetapi, jika jumlah subyeknya besar, dapat diambil 10 sampai 15 persen atau 20 sampai 25 persen atau lebih.

Sedangkan untuk pedagang perantara pengambilan sampelnya menggunakan snowball sampling. Hal ini sesuai dengan pendapat Sugiono (2011) bahwa snowball sampling adalah teknik pengumpulan sampel yang mula-mula jumlahnya kecil, kemudian membesar.

\section{Rancangan Analisis Data}

Untuk mengetahui Saluran Pemasaran padi dari petani sampai ke pengecer digambarkan secara deskriptif.

1. Marjin Pemasaran

Rumus yang digunakan :

$$
\begin{aligned}
\mathrm{MP}=\mathrm{Hj}-\mathrm{Hb} & \\
\operatorname{dimana}: \mathrm{MP} & =\text { Marjin Pemasaran }(\mathrm{Rp} / \mathrm{kg}) \\
\mathrm{Hj} & =\text { Harga Jual } \\
\mathrm{Hb} & =\text { Harga Beli }
\end{aligned}
$$

\section{Keuntungan Pemasaran}

Rumus yang digunakan :

$$
\begin{aligned}
\pi=\mathrm{M}-\mathrm{B} & \quad \text { atau } \quad \mathrm{B}=\mathrm{M}-\pi \\
\operatorname{dimana}: \pi \quad & =\text { Keuntungan Pemasaran } \\
\mathrm{M} & =\text { Marjin Pemasaran } \\
\mathrm{B} & =\text { Biaya Pemasaran }
\end{aligned}
$$

Sedangkan untuk mengetahui besarnya biaya pemasaran yang digunakan 
dalam distribusi komoditas padi dapat diketahui dengan rumus sebagai berikut :

$$
\mathrm{B}=\sum \mathrm{Bp}+\mathrm{BR}+\mathrm{BPR}+\mathrm{B} 1
$$

dimana: $\mathrm{B}=$ Biaya

$\mathrm{BP}=$ Biaya Pengangkutan

$\mathrm{BBM}=$ Biaya Bongkar Muat

$\mathrm{BR}=$ Biaya Retribusi

Resiko

$$
\mathrm{BPR}=\text { Biaya Penanggungan }
$$

B1 = Biaya lain-lain

3. Bagian Harga Yang Diterima Petani (farmer's share)

$\mathrm{FSi}=\mathrm{HP}:$ HE $\times 100 \%$

dimana $:$ Fsi $=$ Bagian Harga Yang

Diterima Petani

$\mathrm{HP}=$ Harga Ditingkat Produsen

$\mathrm{HE}=$ Harga Ditingkat Eceran

\section{Tempat Dan Waktu Penelitian}

Penelitian ini dilaksanakan di Desa

Selasari Kecamatan Parigi Kabupaten Pangandaran, dengan tahapan penelitian sebagai berikut:

1). Tahapan survei pendahuluan, penulisan Usulan Penelitian, dan Seminar Usulan Penelitian dilaksanakan pada bulan Februari 2019.

2). Tahapan pengumpulan dan pengolahan data dilaksanakan pada bulan Maret 2019.

3). Tahapan penulisan laporan penelitian data dilaksanakan pada bulan April 2019 sampai dengan selesai.

\section{HASIL DAN PEMBAHASAN}

\section{Identitas Responden}

\section{Umur Respon}

Faktor umur sangat berpengaruh dalam suatu usaha, dikarenakan pada umur yang lebih muda maka kondisi fisik dan adopsi teknologi cenderung lebih baik daripada yang sudah berumur tua, usia seluruh responden pada umumnya berada pada usia produktif. Hal ini sesuai dengan pendapat Wirosuharjo (2004) yang menyatakan bahwa yang dimaksud dengan penduduk usia produktif adalah penduduk yang berusia antara 15 sampai 64 tahun.

\section{Pendidikan Responden}

Tingkat pendidikan mempengaruhi kegiayan seseorang dalam menjalankan usahanya. Selain itu pendidikan juga merupakan salah satu fatkor yang menentukan sikap seseorang dalam mengambil keputusan khususnya dalam hal penanganan pasca panen karena dengan pendidikan formal maupun non formal seseorang akan bertambah dalam hal pengetahuan, kecakapan ataupun keterampilannya. Pendidikan mempunyai peranan penting bagi responden dalam mengadopsi teknologi dan keterampilan manajemen untuk meningkatkan usahanya. Tingkat pendidikan dalam penelitian ini diukur berdasarkan tingkat pendidikan formal yang pernah dicapai oleh 
responden. Tingkat pendidikan responden umunya adalah tamatan sekolah pendidikan dasar (SD) yaitu sebanyak 13 orang responden, dan tamatan sekolah menengah pertama (SMP) sebanyak 9 orang responden, tamatan sekolah menengah pertama (SMA) 2 orang responden, dan tamatan perguruan tinggi (PT) 1 orang responden.

\section{Pengalaman Berusaha Responden}

Pengalaman yang dimiliki seseorang akan mempengaruhi proses pengambilan keputusan. Demikian pula halnya denga responden bahwa pengalaman usaha yang mereka miliki sangat membantu dalam menjalankan usahanya untuk mendapatkan keuntungan usaha yang lebih baik.

Berdasarkan hasil penelitian, pengalaman berusaha yang dimiliki oleh responden sangat bervariasi. Pengalaman usaha responden sebagian besar antara 5 sampai 10 tahun yaitu sebanyak 20 responden, sedangkan yang mempunyai pengalaman usaha kurang dari 5 tahun sebanyak 1 orang responden, dan yang mempunyai pengalaman lebih dari 10 tahun sebanyak 3 orang responden.

\section{Tanggungan Keluarga Responden}

Salah satu motivasi yang membuat seseorang berusaha berasal dari lingkungan keluarga. Pada dasarnya seseorang akan berusaha memiliki kebutuhan hidup diri dan keluarganya. Keluarga yang menjadi tanggungan dalam hal ini adalah anggota keluarga atau sanak saudara yang tinggal satu rumah dan kebutuhan hidupnya bergantung kepadanya. Seluruh tanggungan keluarga responden kurang dari tiga yaitu 18 orang responden. Dengan demikian pada umumnya kesadaran responden terhadap program keluarga berencana $(\mathrm{KB})$ dapat dikatakan baik. Hal ini dikarenakan sebagian besar anakanaknya telah berkerja atau berkeluarga. Mereka yang masih menjadi tanggungan adalah istri dan anak yang masih sekolah atau belum menikah atau belum berkerja.

\section{Saluran Pemasaran Padi Sawah di Desa Selasari}

Saluran pemasaran merupakan jembatan antara petani dengan konsumen akhir yang melalui berbagai tigkatan lembaga pemasaran. Saluran pemasaran yang dilalui sngat berpengaruh terhadap keuntungan yang diterima oleh masingmasing lembaga pemasaran yang terlibat dalam penyaluran padi sawah. Lembaga yang terlibat dalam pemasaran padi sawah dari petani sampai ke tangan konsumen adalah pedagang pengumpul, pedagang besar, dan pedagang pengecer. 
Berdasarkan hasil penelitian di Desa pemasaran padi sawah seperti yang terlihat Selasari Kecamatan Parigi Kabupaten pada gambar berikut ini :

Pangandaran terdapat sat saluran

Saluran Pemasaran :

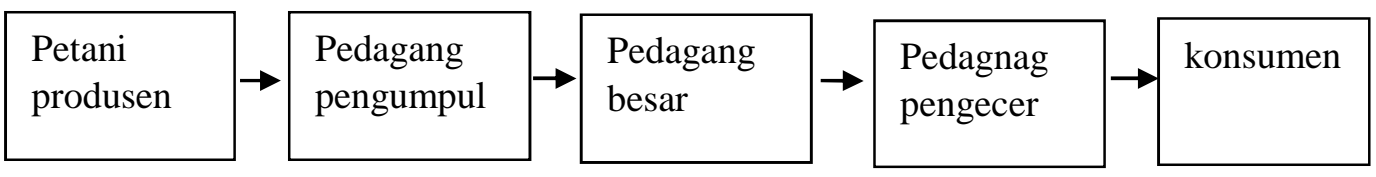

Keadaan Umum Usahatani Padi Sawah

di Desa Selasari Kecamatan Parigi

\section{Kabupaten Pangandaran}

Keadaan umum usahatani padi sawah di Desa Selasari Kecamatan Parigi Kabupaten Pangandaran, kegiatan usahatani padi sawah di Desa Selasari pada umumnya dapat dikatakan hamper seragam baik dalam : pengolahan lahan, persiapan benih, penanaman, pemeliharaan, panen dan pasca panen.

1. Pengolahan tanah

Seluruh petani melakukan pengolahan lahan secara sempurna, karena pengolahan tanah untuk usahatani padi sswah tidak jauh berbeda dengan cara pengolahan padi secara konvensional. Pengolahantanah di desa selasari dilakukan dengan cara lama pada umumnya yaitu pengolahan dilakukan dua minggu sebelum tanam dengan menggunakan traktor dan diikuti dengan pencangkulan kembali karena bertujuan untuk mendapatkan struktur tanah yang baik bagi tanaman.

\section{Benih}

Persiapan benih yang dilakukan oleh petani padi sawah di desa selasari dimulai dari penyortiran benih terlebih dahulu. Penyortiran benih yang dilakukan petai padi sawah di desa selasari bertujuan untuk menyeleksi manakah benih padi yang baik untuk di semai, agar hasil yang didapatkan maksimal.

\section{Penanaman}

Setelah lahan di bajak, lahan yang akan ditanami digaris agar terlihat rapih dan pemberian jarak tanam $25 \times 25 \mathrm{~cm}$ kemudian pembuatan parit di sisi dan di tengan sebagai sistem irigasi. Petani padi sawah di desa selasari menanam benih padi berumur 15-20 hari, ditanam sebanayk 3-5 batang per rumpun dengan kedalaman 4 $\mathrm{cm}$.

4. Pemupukan

Petani responden melakukan pemupukan pertama pada umur 7 hari sebelum tanam dan kedua setelah umue 45 
hari sesudah tanam, denga pemupukan pertam yaitu menggunakan pupuk kompos.

5. Penyulaman

Penyulaman dilakukan petani responden jika ada tanaman padi yang dimakan oleh hama, pada umumnya oleh keong dan hama lainnya.

6. Penyiangan

Petani padi melakukan pemeliharaan tanaman pada vase vegetative dengan melaksanakan penyiangan sebanyak 2 kali, yaitu pada umur 10 hari sebelum tanam dan 45 hari setelah tanam.

\section{Penyemprotan}

Petani responen melakukan penyemprotan sebanyak 3 kali, yaitu penyemprotan pertama pada umur 12 hari sesudah tanam, kedua pada umur 30 hari setelah tanam dan 45 hari setelah tanam dengan menggunakan pestisida.

8. Panen dan pasca panen

Waktu pemanenan padi dilakukan oleh petani responden adalah setelah umur tanam padi mencapai 115-120 hari, setelah gabah kelihatan tua dan menguning atau matang serempak. Panen dilakukan dengan cara memotong batang malainya. Batang dipotong pada bagian bawah dengan menggunakan sabit (arit), kemudian padi dirontokkan dengan cara mengggunakan banting bertirai (gebottan). Penangan pasca panen yang dilakukan oleh petani responden adalah melakukan penjemuran dan penyimpanan yang baik.

Kegiatan Pemasaran Padi Sawah di Desa Selasari

\section{Kegiatan Pemasaran di Tingkat Petani}

Skala usaha padi sawah di Desa Selasari Kecamatan Parigi Kabupaten Pangandaran beragam, baik dalam hal usaha areal tanam maupun banyaknya tanaman padi sawah yang ditanam, sehingga hasilnya bervariasi. Ada petani yang menghasilkan produksi banyak dan ada juga yang sedikit.

Ketika padi sawah mulai berproduksi, petani mulai memanen padi sawah yang telah memenuhi kriteria untuk dipanen. Petani tidak menjual langsung produksinya ke pedagang besar atau konsumen melainkan melalui pedagang pengumpul. Biasanya pedagang tersebut datang langsung ke lokasi produsen atau bahkan ke rumah-rumah produsen untuk membeli padi sawah tersebut sehingga produsen tidak menanggung biaya transportasi, adapun cara pembayaran yang dilakukan oleh pedagang pengumpul ketika menjual produknya yaitu secara tunai dengan harga jual pada padi sawah di tingkat petani besar Rp. 4.000/kg dan 
volume jual padi sawah produsen pada umumnya $1,076 \mathrm{~kg}$.

\section{Kegiatan ditingkat Pedagang \\ Pengumpul}

Pedagang pengumpul adalah pedagang yang membeli produk pertanian dari oetani produsen yang dikumpulkan pada suatu tempat untuk dijual kembali ke lembaga pemasaran lain. Cara pembelian padi sawah oleh pedagang pengumpul yaitu dengan cara mendatangi petani produsen. Padi sawah ditimbang dalam satuan kilogram dengan harga beli saat penelitian sebesar Rp. 4.000 per kilogram dan dibayar dengan cara tunai dengan jumlah volume beli sebanyak 1.076 kilogram.

Rata-rata biaya pemasaran yang dikeluarkan di tingkat pedagang pengumpul dapat dilihat pada Tabel 1 .

Tabel 1. Rata-rata Biaya Pemasaran Padi Sawah Pedagang Pengumpul

\begin{tabular}{llr}
\hline No & Jenis Biaya & $\begin{array}{c}\text { Jumlah Biaya } \\
\text { (Rp) } \\
\text { Saluran } \\
\text { Pemasaran }\end{array}$ \\
\hline 1. & Transportasi & 90.000 \\
2. & Pengangkutan & 60.000 \\
3. & Bongkar muat & 150.000 \\
& Jumlah & $\mathbf{3 5 0 . 0 0 0}$ \\
\hline
\end{tabular}

Tabel 11 menunjukkan, bahwa biaya yang paling besar dikeluarkan pedagang pengumpul adalah biaya bongkar muat sebesar Rp. 150.000, trasportasi Rp. 90.000 dan pengangkutan Rp. 60.000 .

\section{Kegiatan di Tingkat Pedagang Besar}

Pedagang besar adalah pedagang yang membeli padi sawah dalam jumlah banyak yang umumnya berasal dari pedagang pengumpul dan dijual kembali pada pedagang pengecer. Cara pembelian padi sawah yang dilakukan oleh pedagang besar yaitu dengan membeli padi sawah dari pedagang pengumpul dengan harga sebesar Rp. 5.000 per kilogram. Cara pembayaran yang mereka lakukan adalah secara tunai sesuai volume pembelian dan sesuai dengan kesepakatan dengan volume beli padi sawah dari pedagang pengumpul sebanyak 4.000 kilogram.

Sebelum pedagang besar menjual produknya, terlebih dahulu pedagang besar melakukan fungsi pemasaran sebelum menghubungi pedagang pengecer dengan mengolah terlebih dahulu menjadi beras dengan perhitungan 15 persen susut per satu kintal atau denga kata lain $100 \mathrm{~kg}$ gabah menjadi $85 \mathrm{~kg}$ beras.

Beras dijual ke pedagang pengecer dengan rata-rata harga jual beras Rp. 8.500 per kilogram dan volume jual beras sebanyak 340 kilogram. Rata-rata biaya pemasaran yang dikeluarkan dari tingkat pedagang besar dapat dilihat pada Tabel 2 . 
Tabel 2. Rata-rata Biaya Pemasaran Padi Sawah di Pedagang Besar

\begin{tabular}{lll}
\hline No & \multicolumn{1}{c}{ Jenis biaya } & \multicolumn{1}{c}{$\begin{array}{c}\text { Jumlah } \\
\text { biaya(Rp) }\end{array}$} \\
\hline 1 & Transportasi & 520.000 \\
2 & Bongkar muat & 120.000 \\
3 & pengemasan & 150.000 \\
4 & Pajak resmi & 100.000 \\
& Jumlah & \\
\hline
\end{tabular}

Tabel 12 menunjukkan, bahwa biaya yang paling besar dikeuarkan pedagang besar adalah biaya transportasi sebesar Rp. 520.000, bongkar muat Rp. 150.000, pengemasan Rp. 150.000, dan pajak resmi Rp. 100.000.

\section{Kegiatan ditingkat Pedagang Pengecer}

Pedagang pengecer adalah pedagang yang membeli beras dari pedagang besar untuk dijual atau diecerkan pada konsumen.

Cara pembelian beras yang dilakukan oleh pedagang pengecer yaitu dengan membeli beras dari pedagang besar dengan harga beli beras sebesar Rp. 8.500 per kilogram. Dengan cara pembayaran yang dilakukan adalah secara tunai sesuai dengan volume pembelian dan sesuai dengan kesepakatan dengan rata-rata volume beli beras sebanyak 3.400 kilogram. Biaya rata- rata yang dikeluarkan pedagang pengecer adalah biaya pengemasan Rp. 150,00 per kilogram.

\section{Analisis Biaya, Marjin Dan Keuntungan Pemasaran Antar Lembaga Pemasaran}

Setiap lembaga pemasaran akan melakukan fungsi-fungsi pemasaran yang dapat menciptakan kegunaan, baik guna bentuk, guna waktu dan guna tempat sehingga dapat mempermudah konsumen untuk memperoleh padi sawah tersebut. Dalam perlakuan-perlakuan yang dilakukan oleh pedagang perantara agar produk sampai ke konsumen sesuai dengan keinginan. Perlakuan-perlakuan yang dilakukan oleh lembaga pemasaran dapat mempengaruhi besarnya biaya yang harus dikeluarkan oleh setiap lembaga pemasaran serta berpengaruh pula terhadap besarnya marjin dan keuntungan pemasaran. Besarnya biaya yang dikeluarkan oleh petani akan berpengaruh terhadap harga produk dan akan mempengaruhi besar kecilnya nilai share. Untuk lebih jelasnya dapat dilihat pada Tabel 3 
Tabel 3. Rata-rata Biaya, Keuntungan, Marjin Pemasaran, dan Farmers Share Pada Pemasaran Padi Sawah di Desa Selasari Kecamatan Parigi Kabupaten Pangandaran.

\begin{tabular}{|c|c|c|c|c|}
\hline No & Lembaga Pemasaran & Satuan & Nilai & Farmers Share \\
\hline \multirow[t]{3}{*}{1.} & Petani & & & \\
\hline & Volume jual & $\mathrm{kg}$ & 1.076 & 40,00 \\
\hline & Harga jual & $\mathrm{Rp} / \mathrm{kg}$ & 4.000 & \\
\hline \multirow[t]{8}{*}{2.} & Pedagang pengumpul & & & \\
\hline & Volume beli & $\mathrm{Kg}$ & 1.076 & \\
\hline & Volume jual & $\mathrm{Kg}$ & 1.076 & \\
\hline & Harga beli & $\mathrm{Rp} / \mathrm{kg}$ & 4.000 & \\
\hline & Harga jual & $\mathrm{Rp} / \mathrm{kg}$ & 5.000 & \\
\hline & Marjin & $\mathrm{Rp} / \mathrm{kg}$ & 1.000 & \\
\hline & Biaya rata-rata & $\mathrm{Rp} / \mathrm{kg}$ & 400 & \\
\hline & Keuntungan & $\mathrm{Rp} / \mathrm{kg}$ & 600 & \\
\hline \multirow[t]{8}{*}{3.} & Pedagang besar & & & \\
\hline & Volume beli & $\mathrm{Kg}$ & 4.000 & \\
\hline & Volume jual & $\mathrm{Kg}$ & 3.400 & \\
\hline & Harga beli & $\mathrm{Rp} / \mathrm{kg}$ & 5.000 & \\
\hline & Harga jual & $\mathrm{Rp} / \mathrm{kg}$ & 8.500 & \\
\hline & Marjin & $\mathrm{Rp} / \mathrm{kg}$ & 3.500 & \\
\hline & Biaya rata-rata & $\mathrm{Rp} / \mathrm{kg}$ & 890 & \\
\hline & Keuntungan & $\mathrm{Rp} / \mathrm{kg}$ & 2.610 & \\
\hline \multirow[t]{8}{*}{4.} & Pedagang pengecer & & & \\
\hline & Volume beli & $\mathrm{Kg}$ & 3.400 & \\
\hline & Volume jual & $\mathrm{Kg}$ & 3.400 & \\
\hline & Harga beli & $\mathrm{Rp} / \mathrm{kg}$ & 8.500 & \\
\hline & Harga jual & $\mathrm{Rp} / \mathrm{kg}$ & 10.000 & \\
\hline & Marjin & $\mathrm{Rp} / \mathrm{kg}$ & 1.500 & \\
\hline & Biaya rata-rata & $\mathrm{Rp} / \mathrm{kg}$ & 150 & \\
\hline & Keuntungan & $\mathrm{Rp} / \mathrm{kg}$ & 1.350 & \\
\hline \multicolumn{2}{|c|}{ Marjin total } & & 6.000 & \\
\hline \multicolumn{2}{|c|}{ Biaya total } & & 1.440 & \\
\hline \multicolumn{2}{|c|}{ Keuntungan total } & & 4.560 & \\
\hline
\end{tabular}

Tabel 3 menunjukkan, bahwa para pelaku pemasaran dalam proses pemasaran padi sawah ternyata memerlukan biayabiaya yang besarnya berbeda-beda. Biaya total yang dikeluarkan oleh pelaku pemasaran yaitu Rp. 1.440 per kilogram, yang terdiri dari pedagang pengumpul Rp. 400 per kilogram, pedagang besar Rp. 890 per kilogram, dan pedagang pengecer Rp. 150 per kilogram. Biaya yang di keluarkan pedagang besar lebih besar dibandingkan dengan biaya yang dikeluarkan oleh 
pedagang pengumpul dan pedagang pengecer.

Marjin pemasaran ditiap-tiap pelaku pemasaran berbeda-beda, marjin di pedagang pengumpul yaitu sebesar Rp. 1.000 per kilogram, di pedagang besar Rp. 3.500 per kilogram dan di pedagang pengecer Rp. 1.500 per kilogram. Sedangkan marjin total yang diperoleh sebesar Rp. 6.000 per kilogram. Sedangakan keuntungan totl yang diperoleh pelaku pemasaran yaitu Rp. 5.560 per kilogram yang terdiri dari pedagang pengumpul Rp. 600 per kilogram, pedagang besar Rp. 2.610 per kilogram, dan pedagang pengecer $\mathrm{Rp}$. 1.350 per kilogram. Keuntungan yang diperoleh pedagang besar lebih besar dari keuntungan yang diperoleh oleh pedagang pengumpul dan pedagang pengecer.

\section{Bagian Harga Yang Diterima Petani (Farmer's Share)}

Farmer's Share adalah persentase harga yang diterima produsen dari harga yang dibayarkan oleh konsumen. Untung ruginya para petani tidak ditentukan oleh besar kecilnya nilai farmer's share, tetapi dipengaruhi oleh harga produk dan biaya yang dikeluarkan. Berdasarkan hasil penelitian menunjukkan bahwa rata-rata harga jual ditingkat petani Rp. 4.000 per kilogram, dan rata-rata harga yang jual di pedagang pengecer yang menjual ke konsumen sebesar Rp. 10.000 per kilogram, maka besarnya nilai farmer's share nya adalah : Farmer's share $=\mathrm{pf} \times$ $100 \%$

$$
\begin{aligned}
& \operatorname{Pr} \\
= & \underline{4000} \quad \mathrm{X}
\end{aligned}
$$

$100 \%$$$
=40,00 \%
$$

Dari hasil perhitungan diperoleh farmer's share sebesar 40 persen, hal ini menunjukkan bahwa bagian harga yang diterima petani 40 persen dari harga yang dibayarkan oleh konsumen.

\section{KESIMPULAN DAN SARAN}

\section{Kesimpulan}

Berdasarkan hasil penelitian dan pembahasan maka dapat disimpulkan sebagai berikut :

1) Terdapat satu saluran pemasaran padi sawah di $\rightarrow$ Desa Selasari yaitu : Petani Produsen Pagang Pengumpul Pedagang Besar Pedagang Pengecer

$\rightarrow$ Konsumen.

2) Biaya pemasaran padi sawah yang dikeluarkan ditingakat pedagang pengumpul Rp. 400 per kilogram, pedagang besar Rp. 890 per kilogram, 
dan pedagang pengecer Rp. 150 per kilogram, sehingga biaya keseluruhan sebesar Rp. 1.440 per kilogram. Sedangkan keuntungan pemasaran padi sawah ditingkat pedagang pengumpul yaitu Rp. 600 per kilogram, pedagang besar Rp. 2.610 per kilogram, dan di pedagang pengecer Rp. 1.350 per kilogram, sehingga keuntungan keseluruhan sebesar Rp. 4.650 per kilogram. Marjin pemasaran padi sawah ditingkat pedagang pengumpul sebesar Rp. 1.000 per kilogram, pedagang besar Rp. 3.500 per kilogram, dan di pedagang pengecer Rp. 1.500 per kilogram, sehingga marjin total sebesar Rp. 6.000 per kilogram.

3) Farmer's share atau bagian harga yang diterima petani adalah 40 persen dari harga yang dibayarkan konsumen.

\section{Saran}

Berdasarkan pembahasan dan kesimpulan diatas maka saran yang dapat diajukan adalah sebagai berikut :

1) Untuk menjaga di harga petani tetap stabil disarankan petani dan lembaga pemasran lebih sering untuk berinteraksi dan pertemuan agar mampu untuk saling memberikan informasi harga padi sawah dan memotong saluran pemasaran yang panjang.

2) Kepada pelaku pemasaran disarankan agar keuntungan yang diamil di sesuaikan dengan biaya pemasaran yang dikeluarkan sehingga tidak terjadi ketimpangan keuntungan antar lembaga pemasaran.

3) Disarankan kepada petani agar lebih menggunakan input yang bagus sehingga bias meningkatkan dan menjaga kualitas serta kuantitas produksi yang dihasilkan agara dapat bersaing di pasaran, salah satunya dengan menggunakan cara penggunaan bibit yang lebih unggul dan perawatan yang lebih baik.

\section{DAFTAR PUSTAKA}

Arief. 2005. Pemasaran Jasa Dan Kualitas Pemasaran. Bayumedia Pulishing. Malang.

Arikunto. S. 2006. Prosedur Penelitian Suatu Pendekatan Praktik.Rineka Cipta. Jakarta.

Arikunto. S. 2010. Prosedur Penelitian Suatu Pendekatan Praktik. Rineka Cipta. Jakarta.

Wirosuharjo. 2004. Dasar-Dasar Demografi. Fakultas Ekonomi Universitas Indonesia. Jakarta.

Ma'ruf, (2005) Pemasaran Ritel, Gramedia Pustaka Utama Jakarta.

Mulyadi, 2005. Akuntansi Biaya. Edisi Kelima. Yogyakarta ; UPPAMP YKPN Universitas Gajah Mada

Soekartawi, 2002. Prinsip Dasar Manajemen Pemasaran Hasil-hasil 
Pertanian Teori dan Aplikasinya, Raja Grafindo Persada, Jakarta.

BPP. 2018. Data Tanaman Pangan BPP Kecamatan Parigi. Parigi.

Cristoporus dan Sulaeman. 2009. Analisis Produksi dan Pemasaran Jagung di Desa Labuan Toposo Kecamatan Tawaeli Kabupaten Donggala. Jurnal Agroland Vol. 16 No. 2 : 141147.

Dinas Pertanian. Luas Dan Produksi Tanaman Pangan Tahunan Kabupaten Pangandaran Komoditi Padi Dalam Tahun 2018. Kabupaten Pangandaran.

Isyanti, 2010. Efisiensi Pemasaran Cabai Merah Keriting Di Kecamatan Ngemplak Kabupaten Sleman. Mapeta,12(2):166-124.

Nurmanaf, 2003. Perbandingan komoditi padi dengan pangan lain.

Kartadinata, Abas. 2011. Akuntansi Dan Analisis Biaya. Rineka Cipta. Jakarta.

Kotler dan Amstrong. 2005. PrinsipPrinsip Pemasaran Jilid 1 Edisi 8. Erlangga . Jakarta

Kotler. 2006. Manajemen Pemasaran. P.T Indeks Jakarta. Jakarta.

Kotler, P., dan Keller, K.L. 2008. Manajemen Pemasaran, Jilid 1, Penerbit Erlangga. Jakarta

Kotler, P., dan Keller, K.L 2009. Manajemen Pemasaran jilid 2, edisi Ketiga edisi Ketiga belas, Terjemahan Bob Sabran, MM. Jakarta : Penerbit Erlangga

Kotler dan Keller. 2011. Marketing Manajement Edisi 13. Indeks Kelompok Gramedia. Jakarta.
Limbong W.H, Sitorus. 1987 dalam Widiyanti (2008) Pengantar Tataniaga Pertanian. Fakultas Pertanian IPB. Bogor.

Miranda dan WT. Amin. 2005. Manajemen Logistik dan Supply Chain Management. Harvarindo, Jakarta.

Natawigen., H. 2008. Pengendalian hama terpadu (intreged pest control). Amrico,Bandung.

Rahim dan Astuti 2010. Definisi Pemasaran. Rineka Cipta, Jakarta.

Soemartono. 2006. Bercocok tanam padi, Jakarta: Yasaguna CV. Yasaguna.

Sugiono. 2011. Metode penelitiaan bisnis. Afabeta. Bandung.

Sumiati. 2003. Budidaya padi. Penebar swadaya. Jakarta.

Suparyono. 2003. Padi. Jakarta penebar swadaya.

Supriyatna. 2006. Kiat sukses bertani, Solo : CV Aneka.

Surya permana. 2007. Usahatani padi tanah benih langsung (tabela) lembang:BPTP.

Tjirosoepomo, gembong.2002. taksonomi tumbuhan (spermatopyta). Yogyakarta: gajah mada. University press.

Vergara. 2002. Bercocok tanam padi. Jakarta : Proyek Sarana Fisik Bappenas.

Yurianto, 2008 . Analisis Saluran Pemasaran Kacang Tanah. Jurnal Analisis saluran pemasaran kacang tanah 2016. Ciamis.

Widodo. 2007. Mengatasi permasalahan budidaya padi. Penebar swadaya. Jakarta. 